DOI 10.37882/2223-2982.2020.09-2.13

\title{
ФИЗИЧЕСКАЯ И СПОРТИВНАЯ ТРЕНИРОВКА, КАК ФАКТОРЫ УСКОРЕНИЯ АДАПТАЦИИ ВОЕННОСЛУЖАЩИХ ВОЙСК НАЦИОНАЛЬНОЙ ГВАРДИИ К ПРОФЕССИОНАЛЬНОЙ ДЕЯТЕЛЬНОСТИ
}

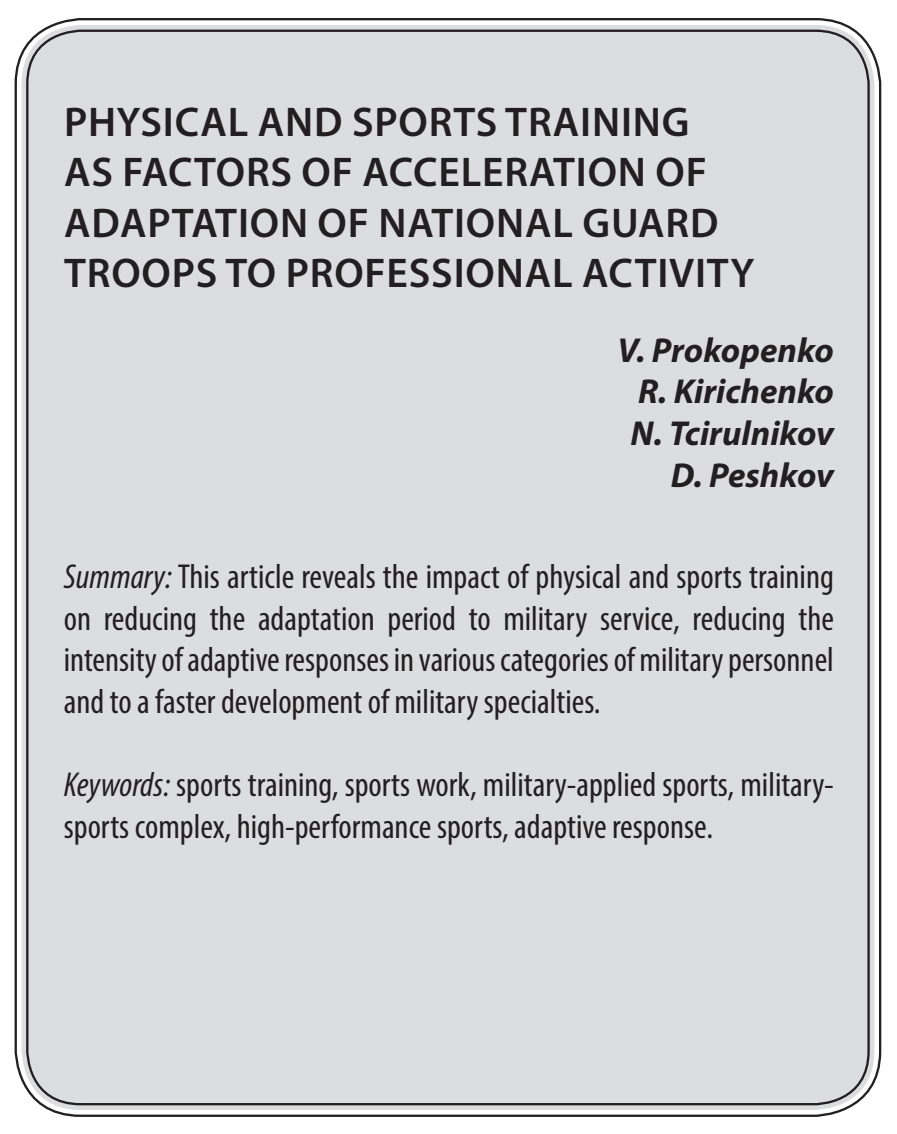

B современных быстро изменяющихся условиях повседневной служебно-боевой деятельности войск национальной гвардии, весьма актуальным становится вопрос об ускорении адаптации военнослужащих к настоящим и новым условиям военной службы.

Быстрота приспособленческих, адаптационных реакций организма военнослужащего к условиям воинской службы зависит от многих факторов.

Весьма важными среди них являются: практика спортивного общения, уровень физической и спортивной подготовленности военнослужащего, функциональные возможности организма.

Занятия массовыми и военно-прикладными видами спорта, практика спортивного общения в ходе спортивных тренировок и соревнований до службы в армии и в период прохождения военной службы, создает высокой

\section{Прокопенко Владимир Викторович}

К.п.н., дочент, Санкт-Петербургский военный ордена Жукова институт войск национальной гвардии Российской Федерачии vvbars@yandex.ru

Кириченко Роман Владимирович K.п.н., Санкт-Петербургский военный ордена Жукова институт войск национальной гвардии

Российской Федерачии orion-3@yandex.ru

Цирульников Николай Николаевич К.п.н., Санкт-Петербургский военный ордена Жукова институт войск начиональной гвардии

Российской Федерачии

Пешков Дмитрий Владимирович Санкт-Петербургский военный ордена Жукова институт войск начиональной гвардии Российской Федерачии

Аннотация: В настоящей статье раскрывается влияние физических и спортивных тренировок на сокращение адаптационного периода к военной службе, снижение напряженности приспособительных реакций у различных категорий военнослужащих к более быстрому освоению воинских специальностей.

Ключевые слова: спортивная тренировка, спортивная работа, военно-прикладные виды спорта, военно-спортивный комплекс, спорт высших достижений, адаптационная реакция.

базовый уровень общей физической подготовленности, а также развития разнообразных двигательных навыков, функциональных возможностей организма [1, с. 7].

Все это позволяет существенно сократить период адаптации к военной службе, снизить напряженность приспособительных реакций, как у молодого пополнения, так и у других категорий военнослужащих.

В результате такие военнослужащие быстрее осваивают новые воинские специальности и достигают в них более высоких результатов.

Ниже мы рассмотрим, как и за счет чего это достигается.

В развитии большинства адаптационных реакций можно выделить два этапа: первый этап - начальной срочной, но несовершенной адаптации (у военнослу- 
жащих, проходящих военную службу по призыву, и у военнослужащих, поступивших на военную службу по контракту); второй этап - совершенной долговременной адаптации.

При разных по характеру сильно действующих факторах внешней среды или деятельности (что может быть характерно для боевой подготовки нового пополнения) устойчивость функций организма, работоспособность обеспечивается физиологическими возможностями одних и тех же систем - систем первой очереди мобилизации.

Если эти системы обеспечивают комплексированный ответ организма на действие факторов среды или деятельности, адаптация протекает в более короткие сроки и с меньшими физиологическими тратами, т.е. при более высоком уровне работоспособности.

Физические упражнения могут эффективно повышать функциональные возможности систем первой очереди мобилизации (срочной адаптации) и, тем самым, ускоряют адаптацию военнослужащих к воинской службе [1, с. 28].

\section{Как это происходит?}

Физиологические системы первой очереди мобилизации включают сердечно-сосудистую систему, систему дыхания и крови.

Функциональные возможности названных систем в наибольшей мере проявляются при работе большой мощности.

Мышечная работа большой мощности позволяет эффективно совершенствовать функциональные возможности рассматриваемых систем. К упражнениям большой мощности относятся такие, которые человек способен выполнять в течение от 5-6 минут до 20-30 минут.

К ним можно отнести бег на 3 и 5 км, марш-бросок на 5 и 10 км, лыжную гонку на 5 и 10 км и другие циклические упражнения.

Под влиянием физической тренировки, с одной стороны, значительно возрастают функциональные возможности физиологических систем организма, с другой, физиологические системы приобретают возможность функционировать при резко сниженном содержании сахара в крови (до 30 мг/\%), чего не наблюдается у слабо тренированных военнослужащих.

Таким образом, применение упражнений, повышающих функциональные возможности физиологических систем срочной адаптации, может значительно ускорить приспособительные реакции военнослужащих нового пополнения к воинской службе [2, с. 19].

Другой, более совершенный этап долговременного приспособления к факторам военно-профессиональной деятельности, заключается в приспособлении самих мышечных тканей к эффективному функционированию при пониженном содержании кислорода во внутренней среде, повышении их устойчивости.

Наиболее выражены указанные явления при выполнении физических упражнений субмаксимальной мощности, когда возникают максимальные физиологические сдвиги.

Продолжительность физической работы субмаксимальной мощности длится от 20-30 секунд до 3-5 минут.

К физическим упражнениям субмаксимальной мощности можно отнести: бег на дистанции от 200 до 1500 метров, преодоление полосы препятствий и другие военно-прикладные упражнения.

Преодоление полосы препятствий служит одновременно и упражнением для эффективного формирования военно-прикладных двигательных навыков, что также способствует ускорению адаптации.

Рассматривая долговременную адаптацию, следует отметить исключительно важную закономерность адаптационных процессов - наличие на клеточном уровне единого механизма приспособления к разнообразным факторам [1, с. 46].

Важность этой закономерности состоит в том, что адаптированный к какому-либо фактору (например: к физическим нагрузкам и т.п.) организм, при изменении условий деятельности (высокогорье, густые лесные массивы, сильно пересеченная местность и т.п.), в более выгодном положении формирует приспособительные реакции к ним, имея уже готовый сформированный на клеточном уровне механизм адаптации.

Это позволяет быстрее перевести приспособительные реакции с системного, на более совершенный тканевой уровень, без резкого снижения работоспособности военнослужащего.

Все это говорит о том, что средствами и методами физической подготовки можно эффективно совершенствовать адаптивные возможности организма как на системном уровне (обеспечивающем срочную адаптацию), так и на тканевом и клеточном (обеспечивающем долговременную адаптацию) и тем самым ускорять адаптацию военнослужащих к военной службе. 
Имеются и другие экспериментально подтвержденные данные, свидетельствующие о важной роли физической подготовки в ускорении адаптации военнослужащих.

Так, трудопотери курсантов вуза в зависимости от уровня развития у них силы и быстроты в пропорциях выглядят, как более 65\% и 60\% трудопотерь соответственно.

Наибольшее влияние на трудопотери курсантов оказывает уровень развития у них выносливости.

У курсантов, имеющих в беге на 3 км оценку «удовлетворительно», трудопотери составили более 70\%, оценку «хорошо» - более $60 \%$, оценку «отлично» - более $50 \%$.

Данные результаты говорят о более успешной адаптации отлично и хорошо физически подготовленных военнослужащих к процессу обучения в военном вузе и о решающей роли при этом физической выносливости [2, c. 25].

Именно физические упражнения циклического характера, развивающие физическую выносливость, наиболее эффективно совершенствуют механизм как срочной, так и долговременной адаптации.

Напряженность адаптации молодого пополнения из числа военнослужащих. проходящих военную службу по призыву, зависит также от успешности самого процесса обучения.

Распределение молодого пополнения по военным специальностям с учетом особенностей физической подготовленности, профессионально важных физических качеств повышает эффективность формирования у военнослужащих боевых навыков и умений, ускоряет процесс адаптации в военной среде, способствует росту их авторитета в коллективе, создает хороший эмоциональный настрой на службу в целом.

При этом физическая тренировка в целях ускорения адаптации военнослужащих позволяет решать следующие задачи:

- расширять функциональные возможности военнослужащих;

- мобилизовать защитные реакции организма;

- ускорять военно-профессиональное обучение;

- способствовать восстановлению организма после напряженной боевой учебы;

- ускорять социально-психологическую адаптацию [2, c. 33].

Каждая из названных задач может быть успешно решена путем применения соответствующих средств и ме- тодов физической подготовки.

Результаты многочисленных исследований, показывают эффективное решение данных задач средствами физической подготовки и спорта.

Например, оценивая работоспособность по частоте сердечных сокращений при выполнении боевых задач в ходе учений у военнослужащих прошедших специальную физическую и спортивную подготовку, направленную на ускорение их адаптации, и военнослужащих занимающихся по обычному плану боевой подготовки, можно с уверенностью говорить о существенном преимуществе первых.

При одинаковых условиях учебно-боевой деятельности частота сердечных сокращений у военнослужащих, занимающихся в обычном плановом режиме, была значительно выше, чем у военнослужащих прошедших специальную физическую и спортивную подготовку, что свидетельствует о более низких функциональных возможностях первых.

Кроме того, у военнослужащих, занимающихся в обычном плановом режиме более выраженное напряжение организма в ходе выполнения учебно-боевых задач, в конечном счете, это приводит к резкому снижению их работоспособности в отличие от хорошо физически подготовленных военнослужащих [3, с. 41].

Таковы теоретические и практические основы применения средств физической и спортивной тренировки для ускорения адаптации всех категорий военнослужащих и сотрудников к условиям военной и служебной деятельности в войсках национальной гвардии России.

В заключение можно сделать вывод, что все формы физической подготовки, в том числе и ее составляющей - спортивной тренировки, вносят весомый вклад в ускорение адаптации военнослужащих к военной службе, способствуют повышению качества их профессионального обучения и мастерства, эффективности в выполнении учебно-боевых и других задач в соответствии с предназначением [4, с. 32].

Высокая личная физическая и спортивная подготовка, будут способствовать развитию широкого диапазона адаптационных возможностей у военнослужащих к внезапно меняющейся и, зачастую, непредвиденной боевой обстановке.

Это позволит военнослужащим в минимальное время и качественно решить любую боевую и другую задачу, стоящую перед войсками национальной гвардии России. 


\section{ЛИТЕРАТУРА}

1. Тарасов М.М, Кононов В.А., Прокопенко В.В., Шипулин А.В. Особенности процесса адаптации молодого пополнения к военной службе средствами физической подготовки: методическое пособие // - СПб.: Санкт-Петербургский военный институт внутренних войск МВД России, 2003.

2. Кононов В.А., Килин В.В., Прокопенко В.В., Иванов А.Г. Физическая подготовка, как фактор ускорения адаптации военнослужащих внутренних войск МВД России к режиму боевой деятельности в условиях горно-пустынной местности: методическое пособие // - СПб.: Санкт-Петербургский военный институт внутренних войск МВД России, 2010.

3. Кириченко И.Е., Лобанов Ю.Я., Прокопенко В.В. Физическая подготовка в вопросах и ответах: методическое пособие // - СПб.: Санкт-Петербургский военный институт внутренних войск МВД России, 2012.

4. Кириченко Р.В., Лобанов Ю.Я. Управление образовательным процессом курсантов и слушателей в условиях личностно-ориентированного обучения (на примере физической подготовки) // Актуальные проблемы физической и специальной подготовки силовых структур. Научный рецензируемый журнал № 4. Санкт-Петербург, 2015

() Прокопенко Владимир Викторович (vvbars@yandex.ru), Кириченко Роман Владимирович (orion-3@yandex.ru)

Цирульников Николай Николаевич, Пешков Дмитрий Владимирович.

Журнал «Современная наука: актуальные проблемы теории и практики»

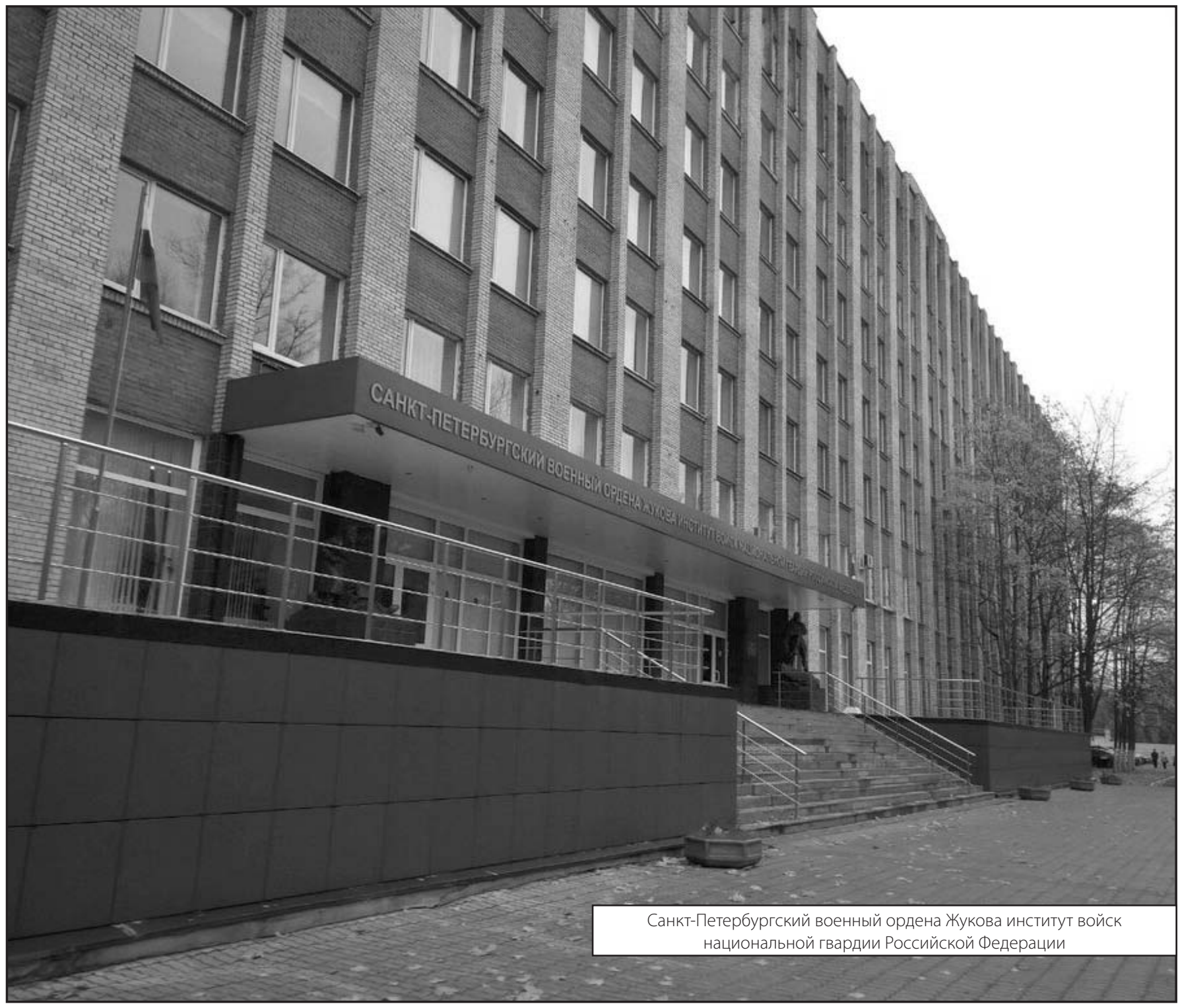

